Kyoung Chan Park • Hyun Ok Choi • Kee Ho Park

Kyu Han Kim • Hee Chul Eun

\title{
A nonsense mutation at Arg-1947 in the NF1 gene in a case of neurofibromatosis type 1 in a Korean patient
}

Received: November 8, 1999 / Accepted: November 15, 1999

\begin{abstract}
We report a case of neurofibromatosis (NF) 1 presenting as a C-to-T transition changing an Arg-1947 codon to a stop codon. Because this mutation has been described in multiple Caucasian and Japanese families, the codon CGA for Arg-1947 in the NF1 gene is considered to be a hotspot for mutation in neurofibromatosis type 1 in all ethnic groups.
\end{abstract}

Key words Hot spot $\cdot$ Mutation · Neurofibromatosis

\section{Introduction}

Neurofibromatosis type 1 (NF-1) is one of the most common genetic disorders in humans and is characterized by neurofibromas, cafe-au-lait spots, axillary freckling, lisch nodules, and a number of severe complications. The NF-1 gene has been cloned and mapped to human chromosome 17q11.2. It has an open reading frame that predicts a protein consisting of 2818 amino acids, known as neurofibromin (Cawthon et al. 1990; Li et al. 1995). Neurofibromin can downregulate p21-Ras-GTP through its highly conserved, central GAP-related domain (GRD) (McCormick 1989). Although many kinds of mutation have been reported in NF1, a C-to-T transition at codon 1937 in exon 31, located downstream of GRD, is considered to be a mutation "hot spot" of the NF1 gene (Klose et al. 1999). In this study, we screened 56 Korean patients with NF1 for the presence of the Arg-1947 mutation by polymerase chain reactionsingle-strand conformation polymorphism (PCR-SSCP) analysis.

K.C. Park $(\bowtie) \cdot$ H.O. Choi $\cdot$ K.H. Park $\cdot$ K.H. Kim $\cdot$ H.C. Eun Department of Dermatology and Artificial Organ Laboratory of Clinical Research Institute, Seoul National University College of Medicine, 28 Yungondong, Chongno-gu, Seoul 110-744, Korea Tel. +82-2-760-1745; Fax +82-2-747-7933

e-mail:kcpark@medicine.snu.ac.kr

\section{Subjects and methods}

Subjects. Fifty-six unrelated Korean patients with NF1 were studied. Clinical information on 56 unrelated patients with NF1 was obtained from the Korean Hereditary Diseases Registry, at the Seoul National University College of Medicine. Fifteen patients had a family history of NF1 and 41 were sporadic. Genomic DNA was prepared from peripheral blood.

DNA amplification. DNA samples for SSCP were generated by using PCR with the primer pairs previously described for exon 31 (Ainsworth et al. 1993). DNAs were amplified at $94^{\circ} \mathrm{C}$ for $30 \mathrm{~s}$, at $52^{\circ} \mathrm{C}$ for $90 \mathrm{~s}$, and at $72^{\circ} \mathrm{C}$ for $2 \mathrm{~min}$, followed by incubation at $72^{\circ} \mathrm{C}$ for $10 \mathrm{~min}$.

Single-strand conformation polymorphism (SSCP) analysis and sequence determination. PCR products were screened for the presence of mutations by SSCP analysis, using MDE gel (FMC, Rockland, MA, USA). The PCR products were mixed with the same volume of loading buffer (95\% formamide, $10 \mathrm{mM} \mathrm{NaOH}, 20 \mathrm{mM}$ ethylenediaminetetraacetic acid (EDTA), $0.02 \%$ bromophenol blue), denatured at $95^{\circ} \mathrm{C}$, and cooled on ice immediately. The single-strand PCR products were then separated on $0.5 \times$ MDE gel. The DNA was visualized by silver staining. Exon segments that showed aberrant patterns were independently reamplified from genomic DNA and cloned into pCR2.1 (Invitrogen, Carlsbad, CA, USA). The complete nucleotide sequences of at least six independent clones were determined. To confirm the presence of the mutation, amplified PCR products were sequenced directly (Fig. 1).

\section{Results and discussion}

In order to screen mutations in the $N F 1$ gene, we performed PCR-SSCP analysis of exon 31 . One patient showed a band with altered mobility. The nucleotide sequence of the 
Fig. 1. Direct genomic sequencing of exon 31. DNA sequences of the normal and mutant alleles are shown. The transition of the codon CGA for Arg-1947 to the stop codon TGA is underlined

\section{T GAT GC CAAAC GACAAAG AGT TAC TAG C TAT T \\ 0 100 110 120}

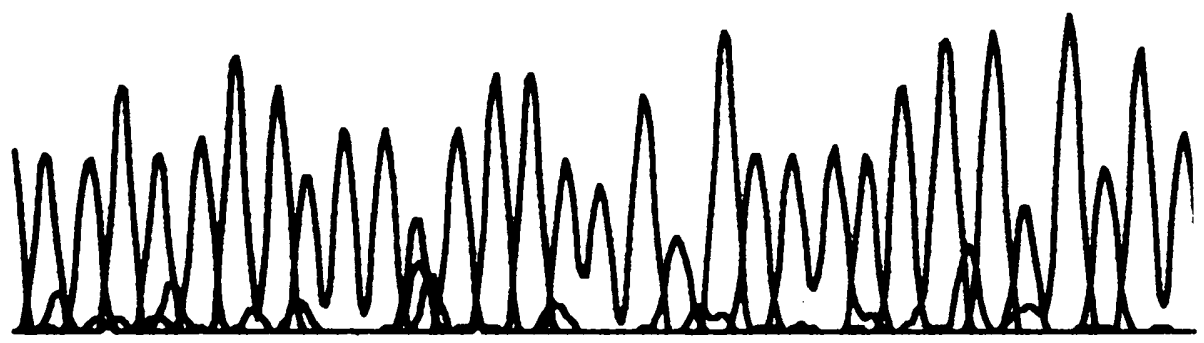

T G A T G C C A A A C A A A A A G A T T A C T G C T A T T :Nomal patient's DNA revealed transition of the codon CGA for Arg-1947 to the stop codon TGA. The patient is a Korean woman, 34 years of age, with multiple cafe-au-lait spots and numerous small cutaneous nodules. There was no family history.

To date, a number of mutations have been found in the $N F 1$ gene. However, reports of a hot spot for mutations in NF1 are not common. Horiuchi et al. (1994) reported a nonsense mutation at Arg-1947(R1947X) in two unrelated patients with familial NF1 in Japan, and this is a hotspot regardless of ethnicity, as the same mutation has been reported in three unrelated Caucasians (Cawthon et al. 1990; Estivill et al. 1991; Ainsworth et al. 1993). Horiuchi et al. (1994) also reported that the frequency of this mutation was $8.0 \%$ in Japan. Several authors have since reported other cases of the R1947X mutation, and Lazaro et al. (1995) suggested that the frequency of this mutation was about $2 \%$. As exon 31 represents only $2 \%$ of the NF1 coding region, it was suggested that the codon for Arg1947(CGA) is the hotspot for mutations in the NF1 gene and that this specific cytosine is particularly prone to mutation. In this study, we found the same mutation in one patient, and frequency can be said to be $1.8 \%$ in Koreans. These results are similar to those reported by Lazaro et al. (1995). These results suggest that routine analysis for the $\mathrm{R} 1947 \mathrm{X}$ mutation is advisable for patients with NF1 in all ethnic groups.

Neurofibromin consists of 2818 amino acid residues containing a region of 360 amino acids called guanosine triphosphate (GTP)ase-activating protein-related protein (GAP), which is structurally and functionally homologous to GTPase-activating protein (GAP) (Xu et al. 1990). As GRD as well as GAP stimulates GTPase and converts the GTP-bound active form of p21ras to the inactive form, it is possible that neurofibromin may act as a tumor suppressor by inactivating the ras oncogene, although the functional properties of other parts of neurofibromin are still unknown. It is reported that a common consequence of $\mathrm{NFI}$ mutations is the introduction of a premature stop codon, and the majority of mutant genes encode truncated forms of neurofibromin (Park and Pivnick, 1998). Exon 31 resides downstream of GRD. If no other mutations reside in the coding region of the mutatnt allele, the mutant message will encode abnormal neurofibromin, which lacks one-third of its carboxy end, but still preserves the GRD. These results suggest that the function of neurofibromin may be modulated by the domain downstream from the NF1-GRD.

Acknowledgments This work was supported by a Grant from the Ministry of Education of Korea (1997).

\section{References}

Ainsworth PJ, Rodenhiser DI, Teresa Costa M (1993) Identification and characterization of sporadic and inherited mutations in exon 31 of the neurofibromatosis (NF1) gene. Hum Genet 91:151-156

Cawthon RM, Weiss R, Xu G, Viskochil D, Culver M, Stevens J, Robertson M, Dunn D, Gesteland R, O'Connell P, White R (1990) A major segment of the neurofibromatosis type 1 gene: cDNA sequence, genomic structure, and point mutations. Cell 62:193-201

Estivill X, Lazaro C, Casals T, Ravella A (1991) Recurrence of a nonsense mutation in the NF1 gene causing classical neurofibromatosis type 1 . Hum Genet 88:185-188

Horiuchi T, Hatta N, Matsumoto M, Ohtsuka H, Collins FS, Kobayashi Y, Fujita S (1994) Nonsense mutations at Arg-1947 in two cases of familial neurofibromatosis type 1 in Japanese. Hum Genet 93:81-83

Klose A, Peters H, Hoffmeyer S, Buske A, Luder A, Hess D, Lehmann R, Nurnberg P, Tinschert S (1999) Two independent mutations in a family with neurofibromatosis type 1 (NF1). Am J Med Genet 83:6-12

Lazaro C, Kruyer H, Gaona A, Estivill X (1995) Two further cases of mutation R1947X in the NF1 gene: screening for a relatively common recurrent mutation. Hum Genet 96:361-363

Li Y. O'Connell P, Breidenbach HH, Cawthon R, Stevens J, Xu G, Neil S, Robertson M, White R, Viskochil D (1995) Genomic organization of the neurofibromatosis 1 gene $(N F 1)$. Genomics 25:9-18

McCormick F (1989) ras GTPase activating protein: signal transmitter and signal terminator. Cell $56: 5-8$

Park VM, Pivnick EK (1998) Neurofibromatosis type 1 (NF1): a protein truncation assay yields identification of mutations in $73 \%$ of patients. J Med Genet 35:813-820

Xu G, O'Connell P, Viskochil D, Cawthon R, Robertson M, Culver M, Dunn D, Stevens J, Gesteland R, White R, Weiss R (1990) The neurofibromatosis type 1 gene encodes a protein related to GAP. Cell 62:599-608 